\title{
Concomitant Tubercular and Fungal Cerebellar Abscess in an Immunocompromised Girl
}

\author{
Bağısıklığı Bozuk Bir Kıะ Çocuğunda Tüberkïler ve Fungal Serebeller \\ Abse Birlikteliği
} \author{
Mehmet Nusret DEMIRCAN ${ }^{1}$ \\ ${ }^{1}$ GATA Haydarpasa Training Hospital, Department of Neurosurgery, Istanbul, Turkey \\ ${ }^{2}$ GATA Haydarpasa Training Hospital, Department of Pathology, Istanbul, Turkey \\ ${ }^{3}$ Bilkent Rehabilitation Center, Department of Pulmonology, Ankara, Turkey \\ ${ }^{4}$ GATA Haydarpasa Training Hospital, Department of Microbiology, Istanbul, Turkey
}

Hakan SIMSEK ${ }^{1}$, Murat KUTLAY ${ }^{1}$, Ahmet COLAK $^{1}$, Aptullah HAHOLU ${ }^{2}$, Hatice KAYA ${ }^{3}$, Mustafa OZYURT ${ }^{4}$,

Correspondence address: Hakan SIMSEK / E-mail: drhakansimsek@gmail.com

\begin{abstract}
Concomitant tubercular and fungal cerebellar abscess is rare and we report the first concomitant recurrent multi-lobulated tubercular and fungal cerebellar abscess in an immunocompromised girl with Histiocytosis-X. She presented with cerebellar abscess history diagnosed during the ongoing treatment for tuberculous meningitis. The abscess was drained. Upon the detection of cerebellar abscess recurrence and pulmonary infection, she was referred to our clinic five weeks after the first surgical intervention. Patient was conscious, co-operating but confused. She had severe cachexia, stiff neck and fever. Fundus examination showed bilateral papilledema. Cranial MR images revealed multiple lobulated lesions. Suboccipital craniectomy was performed and abscess was evacuated in toto. Lesion was multi-lobulated. Thick, yellow-gray purulent material was drained. Histopathological examinations yielded Langhans giant cells,budding and branching fungal structures. Fungal infection was identified. We emphasize that posterior decompression and total resection should be considered first in the management of lesions with mass effect in the posterior fossa. Also the presence of concomitant fatal fungal abscess highlights that although the clinic and former diagnoses of the patient may direct the clinician to a certain pathogen, unusual resistant organisms should not be.
\end{abstract}

KEYWORDS: Cerebellar, Tuberculous abscess, Paecilomyces, Concomitant

öz

Tüberküler ve fungal serebeller abse birlikteliği nadirdir ve biz Histiyositoz X'i de olan bağışıklığı bozuk bir kızda ilk kez aynı anda tüberküler ve fungal tekrarlayan çok odacıklı serebeller abseyi bildiriyoruz. Hasta, devam eden tüberkülöz menenjiti tedavisi esnasında tanısı konmuş serebeller abse hikayesi ile bir hastaneye başvurmuş. Abse boşaltılmış. Tekrarlayan serebeller abse ve akciğer infeksiyonu tespit edilmesi üzerine, ilk cerrahi müdahaleden beş hafta sonra kliniğimize sevk edilmiş. Hastanın şuuru açık, koopere oluyordu ancak konfüze idi. Şiddetli kaşeksisi, ense sertliği ve ateşi vardı. Göz dibi muayenesi iki taraflı papil ödemi ortaya koydu. Kraniyal MR görüntüleri birden fazla lobüllü lezyonlar gösterdi. Suboksipital kraniyektomi yapıldı ve abse bütünüyle boşaltıldı. Lezyon bölümlü idi. Koyu, sarı gri pürülan madde boşaltıldı. Histopatolojik incelemeler Langhans dev hücreleri, tomurcuklanan ve dallanan mantar yapıları ortaya çıkardı. Mantar infeksiyonu tespit edildi. Arka çukurdaki kitle lezyonlarında ilk olarak posterior dekompresyon ve bütünüyle lezyonun çıkarılmasının düşünülmesini vurguluyoruz. Hastanın kliniği ve evvelki almış olduğu tanı hekimi belirli bir patojene yöneltse de beraberinde ölümcül bir mantar infeksiyonunun bulunması, özellikle bağışıklığı yetersiz çocuklarda erken tanı açısından sıra dışı dirençli organizmaların atlanmaması gerektiğini vurgulamaktadır.

ANAHTAR SÖZCÜKLER: Serebeller, Tüberkülöz absesi, Paecilomyces, Birlikte

\section{INTRODUCTION}

Although uncommon, pediatric central nervous system (CNS) abscesses remain a serious, life-threatening neurological condition (3). Those with congenital heart disease, an ongoing infection, or an immunocompromised state are at particular risk. The location tends to vary with a child's age, for example cerebellar abscesses are more common in younger children. The infection results from the seeding of the parenchyma as the consequence of hematogenous spread from remote sources, direct invasion from contiguous infection of non- neural tissues, or from implantation of pathogens following penetrating wounds or surgery (9).

Tubercular brain abscess is uncommon and tubercular cerebellar abscess is rarely reported. Concomitant pyogenic and tuberculous brain abscess is extremely rare (8). On the other hand, immunocompromised patient himself may become the source of infection by the activation of the opportunistic organisms. Most of these cases occur in immunocompromised patients. 
During the past 2 decades invasive fungal infections have emerged as a major cause of morbidity and mortality in the vast spectrum of high-risk immunocompromised patients (1). Opportunistic filamentous fungi as occasional pathogens in the etiology of invasive diseases have been increasingly documented (2).

However, to our knowledge, concomitant fungal abscess and tuberculous abscess of the cerebellum has not been reported before. We describe the first case of cerebellar tuberculous abscess that was further complicated by concomitant fungus isolated from the drained abscess and the specimen from the bronchoalveolar lavage.

\section{CASE REPORT}

A 13-year-old girl with cerebellar abscess recurrence was referred to GATA Haydarpaşa Training Hospital. She had a history of multiple cutaneous abscesses in her infancy and was treated for bronchopneumonia at a university hospital where Histiocytosis $X$ was first diagnosed when she was one year old.

She was initially admitted to a peripheral hospital with the complaint of long lasting, persistent headache, vomiting, and impairment in gait and stance upon which she was evaluated by cranial computerized tomography (CT) and then magnetic resonance imaging (MRI). Clinical findings combined with MR images raised suspect for tuberculous meningitis. Lumbar puncture was performed and diagnosis of tuberculous meningitis was confirmed microbiologically. Antituberculous chemotherapy regimen was started (isoniazid, rifampicin, pyrazinamide and streptomycin). The patient suffered a seizure and computerized tomography (CT) scan of the brain revealed hydrocephalus so she underwent a ventriculoperitoneal shunt (VPS) operation.

At her follow up, MR images were suspicious for abscess formation when she was on antituberculous chemotherapy and after some time the patient was admitted to the hospital with intractable headache. Cranial MR images discerned cerebellar abscess. The abscess in the posterior fossa was drained in a peripheral hospital. Specimen from the cerebellar abscess aspirate showed necrotic brain tissue with granulomatous chronic active inflammation. She presented with headache, imbalance and impairment of gait three weeks after the drainage of the abscess (Figure 1A, B). She was hospitalized again but her clinical condition worsened with additional pulmonary infection, so she was referred to our hospital for further evaluation after fortnight.

At her admission to our hospital, she initially presented with confusion. On examination she was conscious, cooperating and further found to have severe cachexia, stiff neck and fever. Fundus examination showed bilateral papilledema and anisocoria. Pupil reflexes were bilaterally conserved. Lateral eye movement was absent on the left side. There were no signs suggestive of other cranial nerve palsies. New cranial MR images revealed multiple lobulated lesions with cystic and necrotic components in the posterior fossa which occupied both cerebellar hemispheres. They conglomerated especially just beyond the $4^{\text {th }}$ ventricle so as to efface it and the lesions showed nodular and ring enhancement consistent with abscess formation (Figure 2A-C). Compared to the previous cranial MR images of the cerebellum, the lesion seemed to have doubled in one month time with significant mass effect. On her presentation she was febrile and her chest radiograph discerned diffuse infiltration of the lungs suggesting pneumonia (Figure 3). Therefore high resolution thorax CT was also obtained. Bilateral paramediastinal hyperdense nodular lesions were identified. Subpleural and tubular bronchiectasis, bilateral apical bullous and sequel reticulonodular lesions, several cysts of various sizes with distinct thin walls and patchy homogenous hyperdense appearance in the lower lobes were present (Figure 4). Evaluated together with the history of the patient, CT and

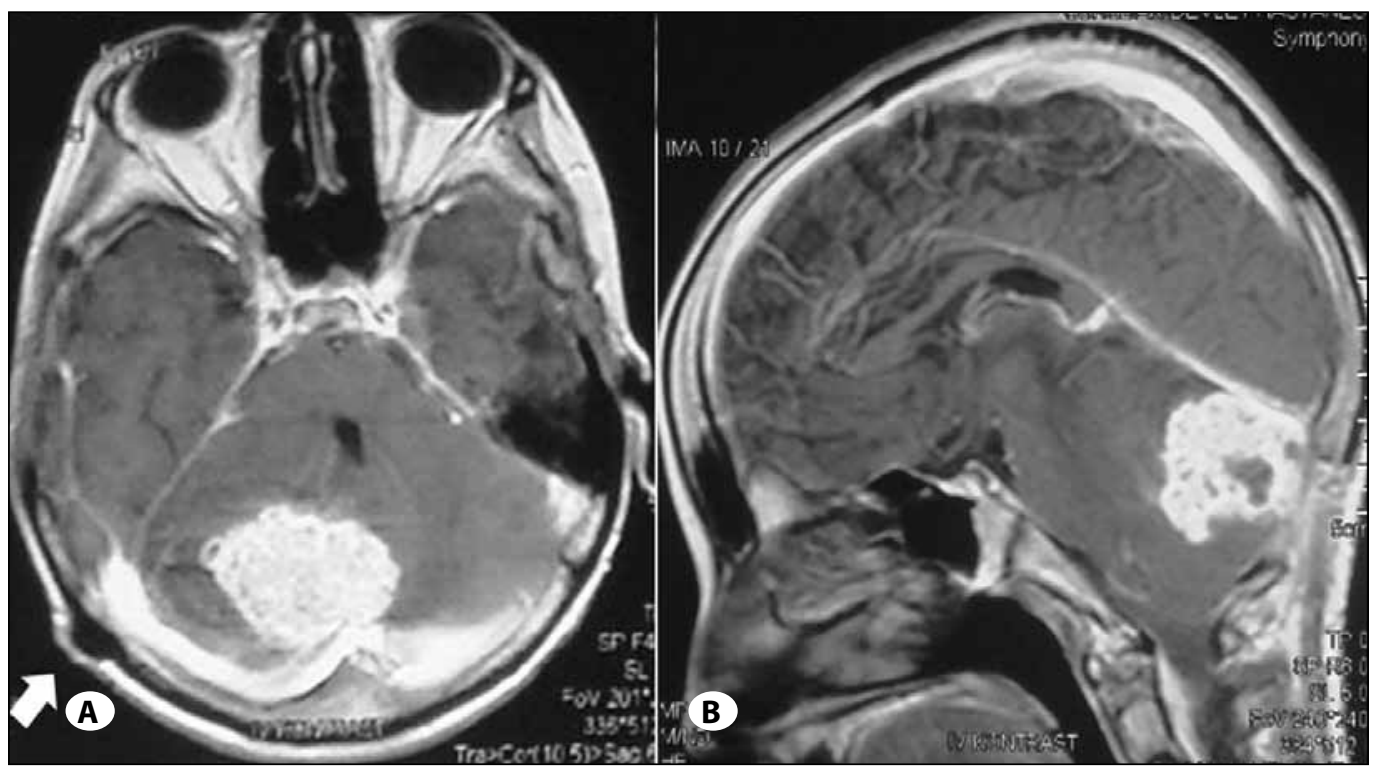

Figure 1: Cranial MR imaging with contrast of the patient which were obtained three weeks before her admission to our hospital showing cerebellar hyperintense lesion attributed to abscess ( $\mathbf{A}$ ) arrow in the axial image points at the burr hole where the abscess had been drained. (B) sagittal image. 


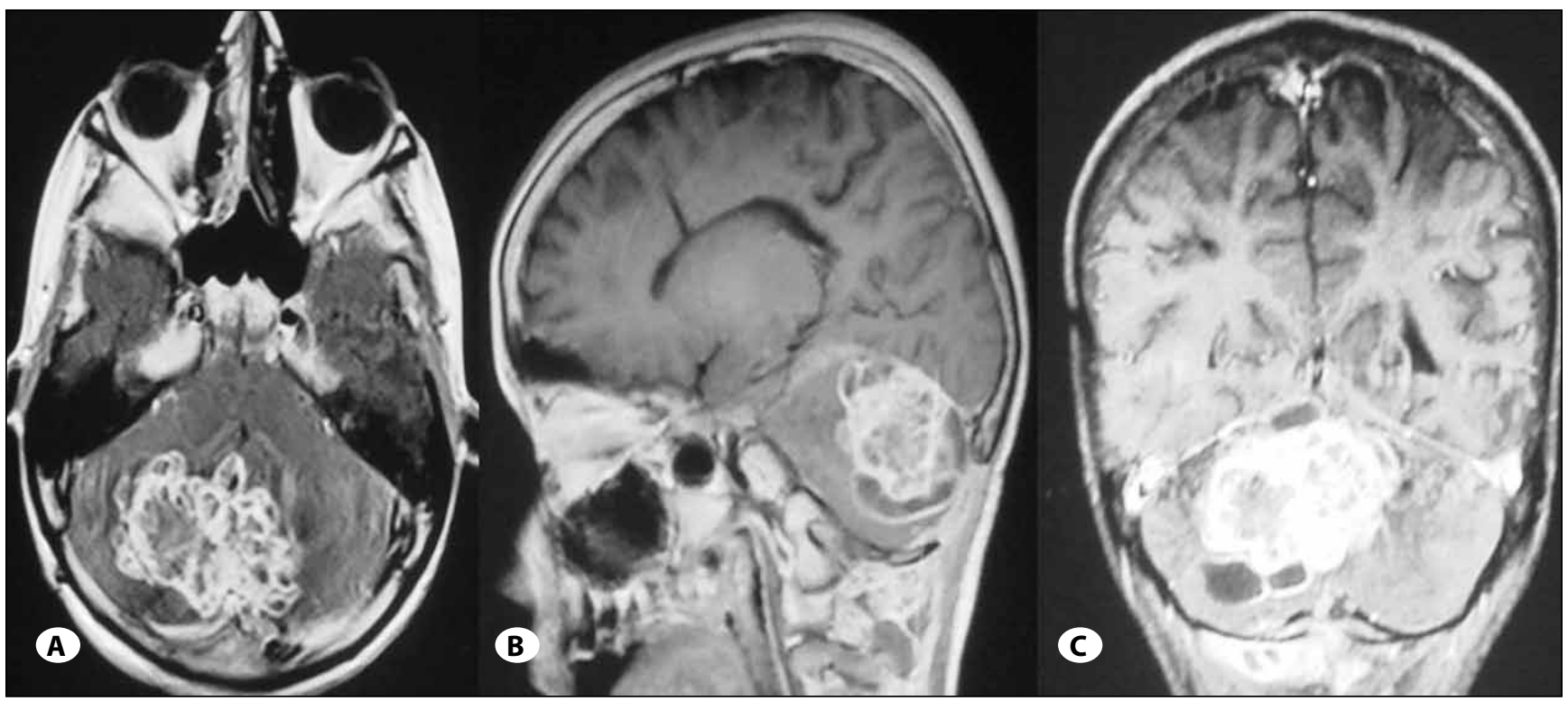

Figure 2: Cranial MR imaging of the patient obtained at her admission to our hospital showing cerebellar lesion with conglomerated ring enhancement on post-contrast study that has enlarged remarkably compared to the previous images of the lesion. (A) Axial, (B) sagittal, (C) coronal views. Circumferential and nodular contrast enhancement with cystic and necrotic foci suggests abscess formation. Because of the mass effect of the lesion and parenchymal edema, the $4^{\text {th }}$ ventricle is obstructed and pons is compressed posteriorly.

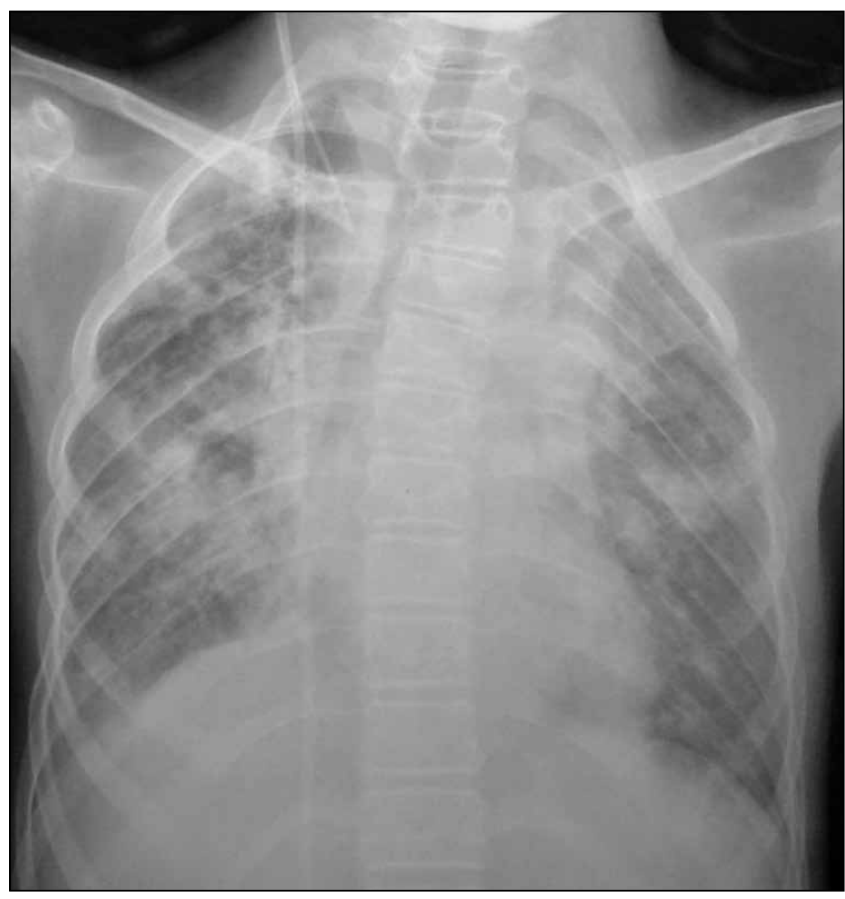

Figure 3: Posteroanterior chest radiograph shows typical reticular, cystic and nodular abnormalities of pulmonary histiocytosis $X$. The upper lungs are predominantly afflicted, whereas the costophrenic angles are not.

radiograph of the chest, suggested interstitial pneumonia and histiocytosis X. Her leucocyte count was 15,600, C-reactive protein was $342 \mathrm{mg} / \mathrm{L}$, and sedimentation rate was $110 \mathrm{~mm} / \mathrm{h}$. Her $\lg A$ was $0.5 \mathrm{~g} / \mathrm{L}$ (reference values: 0.82-4.53) She was given six doses of human IgG $10 \mathrm{~g}$ via the iv route. Empirical broad-

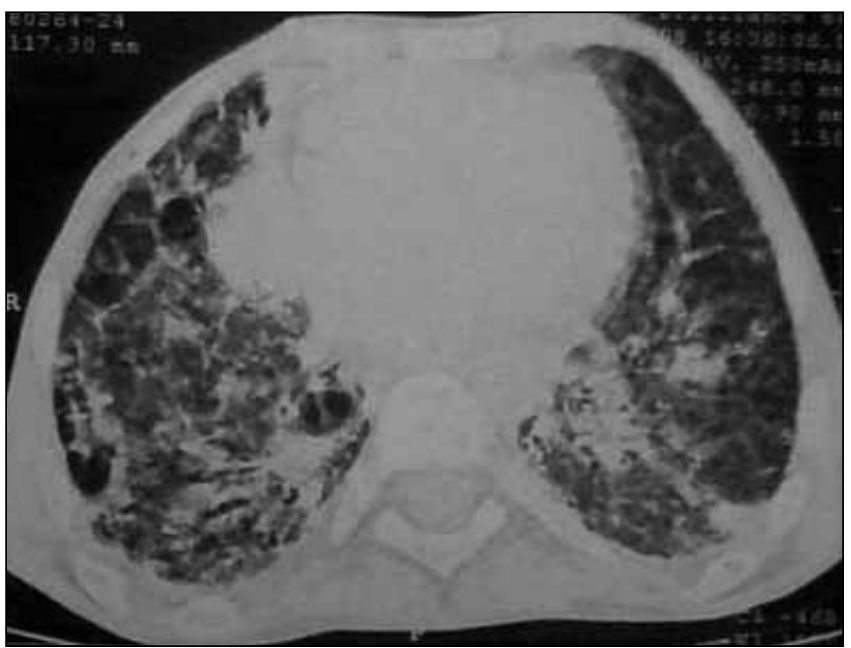

Figure 4: High resolution CT scan of the chest of the same patient showed cysts with distinct thin walls. In the right side the abnormality is more apparent, and the cysts abut each other.

spectrum antibiotics (trimethoprim-sulfametoxazole and meropenem) were initiated. The abscess had a mass effect and suboccipital craniectomy was performed. The patient was taken to the neuro-intensive care unit postoperatively. She was stable and tolerated room air well.

Thick, yellow-gray purulent material was drained from the abutting abscesses.

The frozen section showed necrotic neural tissue with caseified granulomatous inflammation suggestive of cerebellar tuberculous infection. The Gram-stained smear of the pus showed no organisms, while the Ziehl Neelsen staining also 
did not reveal acid fast bacilli other than pus cells. The specimen from the cerebellum and pus consisted of multiple tiny pieces of grayish soft and necrotic tissue. The histopathological examination showed caseified necrotic cerebellar lesions, inflammatory cells, Langhans giant cells and we were warned by the pathologist about a concomitant fungal and tuberculous infection, because careful examination of the specimens with various stains under appropriate magnification identified fungal elements embedded in the Langhans giant cells. (Figure 5A-D) Gomori methenamine silver (GMS) stain was positive for numerous branching and budding septate hyphae. As her fever persisted in the postoperative period while she was on broad-spectrum antibiotics, amphotericin B (AMB), 1 $\mathrm{mg} / \mathrm{kg}$ of body weight/day, was initiated for presumed fungal infection as per the histopathological examinations revealed.

At the same time some samples were inoculated on blood agar, chocolate agar, thioglycollate broth and LowensteinJensen medium. No growth was observed even after prolonged incubation. Culture on Lowenstein Jensen media was also negative. Tbc PCR studies on the abscess aspirate, cerebellar tissue, deep pulmonary aspirate obtained by bronchoscope postoperatively were all negative for Mycobacterium tuberculosis. The aspirates of the cerebellum abscess and bronchoalveolar lavage were plated also on Sabouraud dextrose agar (SDA). Meantime, the patient's respiration was impaired. She was entubated and supported mechanically.

After a week, culture of the aspirates yielded several colonies of fungus closely resembling a Paecilomyces species based on its formation of conidia in short chains (Figure 6A-D). The isolate was referred to the Mycology laboratory, subdivision of Department of Microbiology GATA Ankara, for confirmation and further identification. Paecilomyces variotii was identified as a very rare pathogen.

Progression of pulmonary lesions detected via bronchoscopy and chest radiographs confirmed necrotizing fungal pneumonia with positive culture. Continuation of persistent fever while receiving $A M B$ and isolation of the Paecilomyces spp from both cerebellar and pulmonary specimens suggested fungemia, therefore antifungal therapy was switched to liposomal AMB (LAMB) $(5 \mathrm{mg} / \mathrm{kg} /$ day).

Our patient did not demonstrate clinical and radiological improvement despite the administration of a combination therapy that consisted of high dose LAMB and broadspectrum antibiotics, and she eventually became ventilator dependent on the $8^{\text {th }}$ day of her operation. There was no further improvement and she died two weeks after the operative procedure.

\section{DISCUSSION}

Children with new neurological signs or continued abscess growth despite antimicrobial therapy that is deemed appropriate based on the causative microorganism require additional surgical procedures. In children in whom the abscess remains enlarged and the patient presents with fulminant neurological deterioration despite aspiration and medical management, strong consideration should be given to the performance of a craniotomy to allow more adequate evacuation of the purulent material and debridement of the surrounding parenchyma aiming to identify and cure a concomitant and most of the time, resistant pathogen (9). The aforementined circumstances should alert the clinician against three fatal conditions:

First, the mass effect of the abscess in the posterior fossa no matter which side or sides it inoculates might be extremely fatal, especially in childhood. Compression of the brain stem necessitates immediate release. As an abscess grows, intracranial pressure will increase and there is the potential for herniation. Therefore, the presence of papilledema noted on physical examination requires prompt radiological evaluation and the initiation of measures such as anti-edema treatment and immediate neurosurgical intervention to reduce intracranial pressure consisting of decompression via suboccipital craniectomy (9). Drainage through a burr hole seems not to be curative, and if performed, these patients should be under close observation in an equipped intensive care setting that has rapid access to neurosurgical intervention.

Second, improved imaging techniques combined with improved culturing techniques and advances in surgical and medical management of cerebellar abscesses have contributed to the reduction in the mortality rate in general patient population, which has been seen over the last century. However, this condition remains life-threatening especially in children who are immunocompromised, who present with significant surgery-related neurological deficits and whose initial diagnosis was delayed till the abscess had been disseminated (10).

Third, most infections in compromised hosts are similar in their clinical presentation to those in the normal host. The compromised host is different than the normal host in the distribution of pathogens, which is determined by the nature of the host defense defect. In compromised hosts, differential diagnostic possibilities are more extensive and it unfortunately may take time. Usually the patients do not have enough time for that. An abscess that doubles in size so fast and a fulminant clinical course should remind the complication of abscess by one of those opportunistic mycoses which have been reported as the emerging causative agents in the immunocompromised. Opportunistic fungal infections have become important causes of morbidity and mortality in patients with compromised host defenses. Recent epidemiological trends indicate a shift towards previously uncommon fungi which are increasingly encountered as pathogens of life-threatening infections that are often refractory to conventional therapies (5). Therefore, though the patient may have a previously established diagnosis of a primary pathogen, the physician should not be stuck to that and must be vigilant concerning any concomitant pathology particularly in the immunocompromised. 


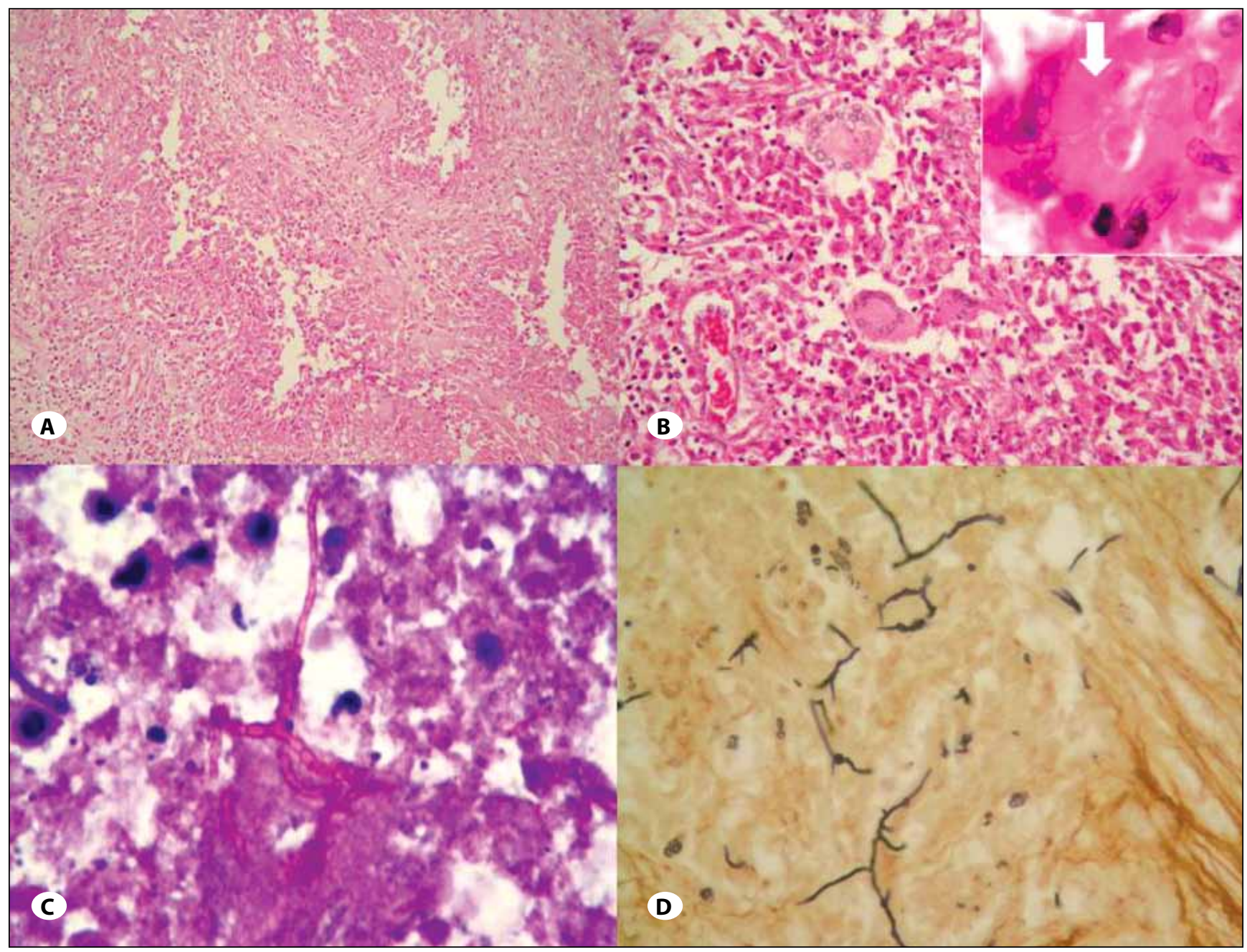

Figure 5: Histopathological examinations revealed (A) necrotic areas in the excised cerebellar lesion (Hematoxylin \& Eosin stain, $x 100)$, (B) histiocyte-rich inflammation consisting if Langhans type giant cells around the necrotic area (Hematoxylin \& Eosin stain, $x 200$ ) and fungal elements within the giant cells (inset) (Hematoxylin \& Eosin stain, $x 400$ ), (C) budding and branching fungi with Periodic Acid Schiff staining (x400), (D) numerous budding and branching fungi structures also with Gomori methenamine silver staining (x400).

The diagnostic approach to the immunocompromised host with central nervous system (CNS) infection may beestablished with an analysis of the patient's clinical manifestations; the acute or subacute onset of the clinical presentation and an analysis of the type of immune defect compromising the patient's defenses. Most patients with CNS infections may be grouped into those with meningeal signs, or those with mass lesions, or both as in the presented case. Compromised host with impaired $\mathrm{T}$ cell or macrophage functions usually tend to develop CNS infections caused by intracellular pathogens like fungi, some other bacteria and viruses (4). Patients with histiocytosis $\mathrm{X}$ unluckily are vulnerable to many systemic infections, some of which might have fatal courses. Less common pathogens are increasingly being documented as occasional causes of infections involving CNS $(5,7)$. Paecilomyces is one of the abovementioned rare causative agents. It is a filamentous fungus found worldwide which inhabits the moist soil, decaying plants and wood.
Paecilomyces variotii and Paecilomyces lilacinus are the most common species associated with paecilomycosis in human. Review of the literature suggests that paecilomycosis causes substantial morbidity and the infection can rapidly be fatal despite adapted antimycotic therapy $(4,6)$.

Although a vigilant approach is useful in limiting diagnostic possibilities, a specific diagnosis still is essential in compromised hosts in order to describe effective therapy. In the management of the relevant case, the vigilance of the pathologist and coordination between the disciplines besides prompt surgical intervention gave the patient a chance. However the intricate systemic failures the patient encountered since her birth depleted her. Therefore, initially the appropriate interventional treatment of the cerebellar abscess consisting of suboccipital craniectomy and prompt diagnosis, and second, microorganism-specific aggressive medical treatment as per their susceptibility appear to be the two mainstays in the management of such complicated cases to decrease neuro- 


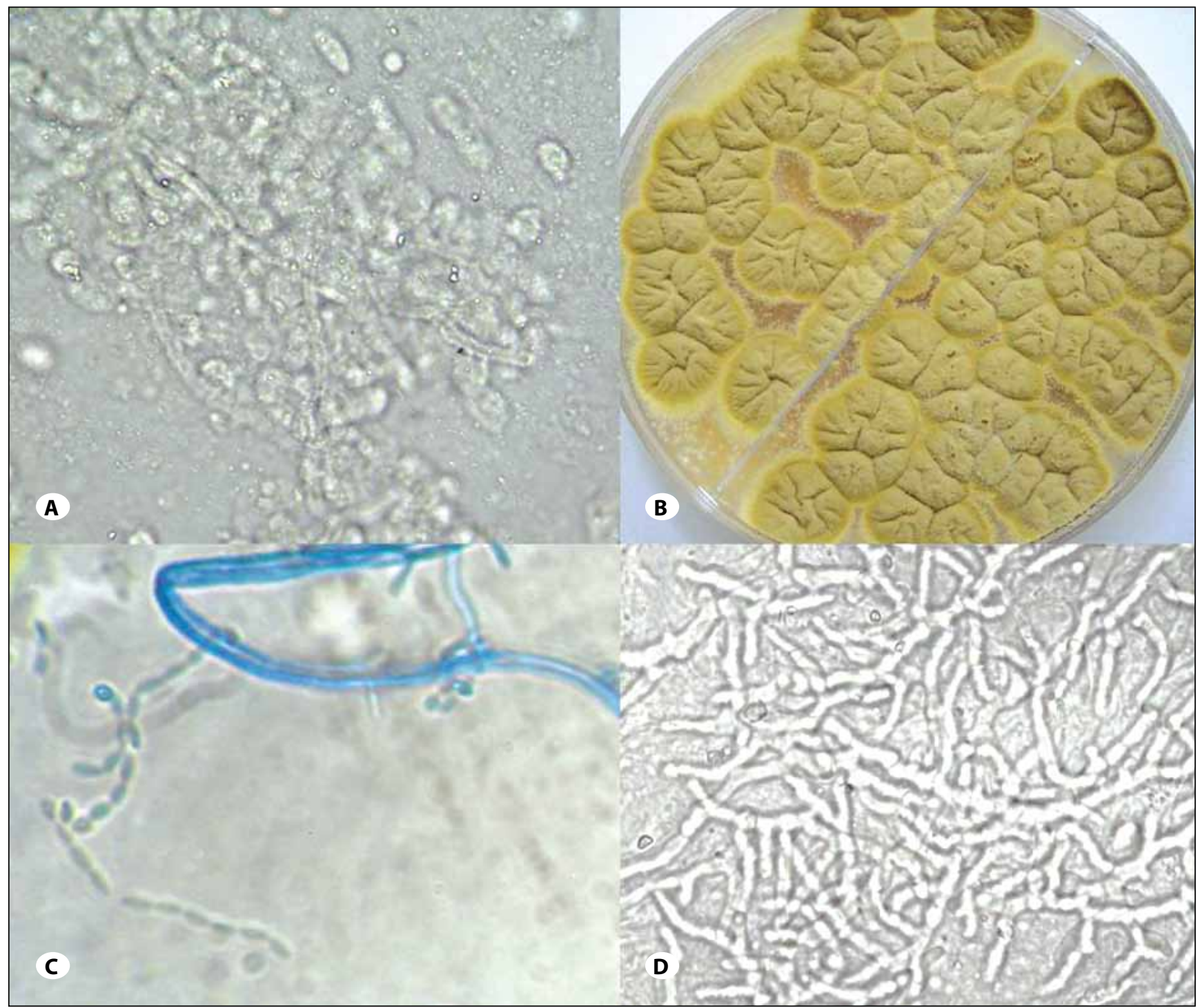

Figure 6: (A) Examination of the specimen that was obtained from the bronchoalveolar lavage by direct microscope with Potassium Hydroxide solution (10\%) discerned fungal elements and many leucocytes (B) Colonies which grew in the Sabouraud dextrose agar medium after a week (C) Phialides branching in the conidiophores, ellipsoidal conidias forming a short chain, and few chlamydospores are discerned by Lactophenol Cotton Blue Staining in the Sabouraud dextrose agar culture (x400). (D) Examination of the Sabouraud dextrose agar culture with Potassium Hydroxide solution (10\%) discerned dense branching phialides (x400).

logical morbidity and the risk of death. However, concomitant Paecilomycosis in an immunocompromised host has proven to be fatal despite available treatment modalities. This is the first case of concomitant cerebellar tuberculous abscess and fungal abscess caused by Paecilomyces variotii in an immunocompromised patient with underlying histiocytosis $\mathrm{X}$.

\section{CONCLUSION}

This case highlights the importance of performing craniectomy to provide proper evacuation and irrigation of the abscess particularly in the posterior fossa, rather than draining the abscess through a burr hole. That a secondary fungal infection developed over cerebellar tuberculous abscess in the presented case, demonstrates the need for proper histopathological evaluation and routine examination of all brain abscesses for fungi and tuberculous organisms besides bacteria, especially in those with evidence of impaired host defense.

\section{REFERENCES}

1. Al-Mohsen IZ, Sutton DA, Sigler L, Almodovar E, Mahgoub N, Frayha H, Al-Hajjar S, Rinaldi MG, Walsh TJ: Acrophialophora fusispora brain abscess in a child with acute lymphoblastic leukemia: Review of cases and taxonomy. J Clin Microbiol 4569-4576, 2000

2. Baddley JW, Moser SA, Sutton DA, Pappas PG: Microascus cinereus (anamorph Scopulariopsis) brain abscess in a bone marrow transplant patient. J Clin Microbiol 38:395-397, 2000 
3. Britt RH, Enzmann DR, Yeager AS: Neuropathological and computerized tomographic findings in experimental brain abscess. J Neurosurg 55:590-603, 1981

4. Cunha B: Central nervous system infections in the compromised host: A diagnostic approach. Infect Dis Clin North Am 15: 567-590, 2001

5. Groll $A H$, Walsh TJ: Uncommon opportunistic fungi: New nosocomial threats. Clin Microbiol Infect. 7 Suppl:8-24, 2001

6. Haldane EV, Mc Donald JL, Gittens WO, Yuce K, van Rooyen CE: Prosthetic valvular endocarditis due to the fungus Paecilomyces. Can Med Assoc J 2(111):963-968, 1974
7. Iwen PC, Sigler L, Tarantolo S, Sutton DA, Rinaldi MG, Lackner RP, McCarthy DI, Hinrichs SH: Pulmonary infection caused by Gymnascella hyalinospora in a patient with acute myelogenous leukemia. J Clin Microbiol 38:375-381, 2000

8. Ramesh VG, Sundar KS: Concomitant tuberculous and pyogenic cerbellar abscess in a patient with pulmonary tuberculosis. Neurol India 56:91-92, 2008

9. Sheehan JP, Jane JA, Ray DK, Goodkin HP: Brain abscess in children. Neurosurg Focus 24(6:E6), 2008

10. Tekkok IH, Erbengi A: Management of brain abscess in children: Review of 130 cases over a period of 21 years. Childs Nerv Syst 8:411-416, 1992 